\title{
Prevalence of Salmonella Strains in Cattle Breeding in the District of Abidjan (Côte d'Ivoire)
}

\author{
Yao Kouamé René ${ }^{1,2} *$, Coulibaly Kalpy Julien², Cissé Souleymane ${ }^{2}$, \\ Tiécoura Kouakou Bertin ${ }^{2}$, Goualié Glossi Bernadette ${ }^{4}$, Gueu Kpon Roméo ${ }^{2}$, \\ Yapi Houphouët Felix ${ }^{1}$ et Djaman Alico Joseph ${ }^{1,3}$
}

\author{
${ }^{1}$ Laboratory of Pharmcodynamie Biochimique, UFR Biosciences, University of Félix \\ Houphouët- Boigny, Abidjan, 22 PO BOX 582 Abidjan 22, Ivory Coast \\ ${ }^{2}$ Laboratory of Microbiology of Food, Institut Pasteur de Côted'Ivoire, \\ PO BOX 490 Abidjan 01, Ivory Coast \\ ${ }^{3}$ Laboratory of Biochemistry, Institut Pasteur de Côted'Ivoire, \\ PO BOX 490 Abidjan 01, Ivory Coast \\ ${ }^{4}$ Laboratory of Biotechnology, UFR Biosciences, University of Félix Houphouët- Boigny, \\ Abidjan, 22 PO BOX 582 Abidjan 22, Ivory Coast \\ *Corresponding author
}

\section{A B S T R A C T}

\begin{tabular}{|l|}
\hline K e y w o r d s \\
Salmonella, \\
serotype, \\
Resistance, \\
Cattle breeding, \\
Côte d'Ivoire.
\end{tabular}

Salmonella is an enterobacterium present in the environment as well as in a large number of animals which, in most cases, serve as host asymptomatically. This bacterium is the leading cause of collective food poisoning in the world. In view of the expansion of salmonellosis in the world and the emergence of multi-resistant strains of Salmonella, this is a threat to human safety. The aim of this study is to determine the prevalence rate of Salmonella and their antibiotic resistance profile, antibiotics often used in cattle breeding in the district of Abidjan. In this study, we were able to analyze 420 samples of cattle fecal and 84 strains of Salmonella (20\%) were isolated. Twenty-three (23) different serotypes were identified. Some of these strains were resistant to the antibiotics used. In view of the outbreak of salmonellosis and the emergence of multidrug-resistant strains Salmonella, biosecurity measures have to be adopted in cattle breeding in order to avoid the risk of food poisoning in the population.

\section{Introduction}

Salmonella is a gram-negative bacterium that belongs to the enterobacteria family (Yan et $a l ., 2003)$. It is present in the environment as well as in a large number of livestock which, in most cases, host it asymptomatically. This bacterium can survive in the environment for a very long period of time, thus contributing to the maintenance of the bacterium within the animal reservoir (Lailler et al., 2015).
Salmonella is the main cause of collective Food Borne Disease Outbreak (FBDO) both in the developed and underdeveloped countries (Dubroca et al., 2005; Bean et al., 1997; Flint et al., 2005; Karou et al., 2013).

A high increase in infections caused by Salmonella present in human foods was noted in the United States, Europe and Korea. These 
infections involved Salmonella enteritidis and Salmonella typhimurium (Brooks et al., 2012; Janmohamed et al., 2011; Jung et al., 2007).

In most cases the food products, mostly contaminated are of animal origin, such as beef, poultry, milk or eggs, but any food, including fruits and vegetables can also be contaminated (Movassagh et al., 2010).

In Côte d'Ivoire, beef as a source of animal protein occupies an important place in the daily diet of the population. In 2004, Ivorian total meat production was 171000 tonnes and meat consumption requirements were covered at $94 \%$ by total meat production (Assoumy, 2009). This implied a higher risk of salmonellosis transmitted by cattle. In addition, salmonellosis in animals still presents a potential danger of zoonotic disease (Donough et al., 1999).

In Côte d'Ivoire in general and in the district of Abidjan in particular, no data or information concerning the circulation of Salmonella in cattle breeding are available.

Faecal matter is a major source of contamination by direct contact or contamination of the environment. Salmonella contamination has enormous consequences, pathological, hygienic and economical consequences, due to the losses induced by animal and human pathologies on one hand and due to the high costs associated with Salmonella contamination control measures on the other hand (Coulibaly et al., 2010).

In this context, Salmonellae constitute a serious threat to the health of our population, due to the spread of salmonellosis in the world and the emergence of multidrug resistant strains of Salmonella. The objective of this study was to determine the prevalence rate of Salmonella in cattle breeding in the district of Abidjan and their resistance profile.

\section{Materials and Methods}

\section{Study area}

This is a cross-sectional study on cattle breeding sites and livestock markets in five (5) municipals in the district of Abidjan: Port Bouët, Abobo, Adjamé, Yopougon and Bingerville. Two of these five municipalities are a popular cattle breeding sites (Port-Bouët and Bingerville), while the other three are mainly livestock markets (Abobo, Adjamé and Yopougon). In Port-Bouët, the samples were collected from three (3) sites, i.e., at the farm, the slaughterhouse and from the livestock open market. These sites were chosen on the basis of their significant inflows of livestock destined for breeding, sale and consumption by the population of the district of Abidjan and also sincere cooperation of all the operators involved (farmers, sellers and owners of livestock) to participate in the study. The sites selected supplied a large amount of beef to the population of the district of Abidjan.

\section{Sampling}

The sampling consisted of collecting fresh cow dung from the cattle just after defecation on the various livestock sites. A total of 420 samples were collected from April to September 2016. During each exercise 30 cow dung samples were aseptically collected in sterile containers and transported to the microbiology laboratory of the Pasteur Institute of Cocody within one hour after collection, in an ice chest containing cold accumulator for analysis upon arrival.

\section{Culture and identification of strains}

All strains were isolated according to the protocol described by standard ISO6579 (2002E). Twenty-five (25) g of cow dung were pre-enriched in $225 \mathrm{~mL}$ of Buffered- 
Peptone water (BPW) (Liofilchem $\AA$ ) in a stomacher bag and incubated at $37{ }^{\circ} \mathrm{C}$ for 24 hours. After $0.1 \mathrm{~mL}$ of pre-enriched broth was added to $10 \mathrm{~mL}$ of Rappaport Vassiliadis broth (RV 10) (Bio-Rad) and incubated at $44^{\circ} \mathrm{C}$ for 24 hours. From each Rappaport Vassiliadis suspension, Hektoen agar (OXOID®) in Petri dishes were streaked and incubated at $37^{\circ} \mathrm{C}$ for 24 hours. The suspected colonies retained exhibited morphological and biochemical characteristics as follows (Table 1).

The strains of Salmonella sp isolated were confirmed by MALDI-TOF Vitek MS (Bio Mérieux, France). Escherichia coli ATCC 8739 (Biomérieux, France) was used as a MALDI-TOF calibrating strain.

\section{Serotyping of strains of Salmonella sp}

Serotypes were determined by agglutination tests slide with anti-serum $\mathrm{O}, \mathrm{H}$ and $\mathrm{Vi}$ (Bio Mérieux, France). Reading the results was made according to the Kauffmann White (1934) scheme.

\section{Antimicrobial susceptibility testing}

Salmonella strains were tested for their susceptibility to different antibiotics using Kirby-Bauer disc diffusion method (Bauer et al., 1966). An inoculum was prepared with colonies of pure culture of 24 hours onto nutrient agar (Mueller Hinton agar) in Petri dishes. These colonies were emulsified in a tube of $10 \mathrm{~mL}$ of Salt water in order to obtain a homogenous suspension of density equivalent to $0.5 \mathrm{Mc}$ Farland standards. A sterile swab was moistened in the bacterial suspension, and Miller-Hinton agar previously dried was seeded by swabbing the entire surface of agar by scoring tightened. The antibiotic disks were disposed onto the surface of the dried agar medium and the agar was incubated for 24 hours. After incubation, agar plats were read by measuring the diameters of inhibition zones around each antibiotic disk with the ADAGIO software (BioMérieux, France). The interpretation of the results was carried out according to the standard of the Antibiogram Committee of the French Society of Microbiology (CA-SFM / EUCAST 2014). A reference Strain of E. coli ATCC25922 $\left(\right.$ OXOID $\left.^{\circledR}\right)$ was tested as a quality a positive control for susceptibility testing. The following antibiotics were tested: Ampicillin $(10 \mu \mathrm{g})$, Amoxicillin + clavulanic acid $(30 \mu \mathrm{g})$, Cefalotin $(30 \mu \mathrm{g})$, Cefepime (30 $\mu \mathrm{g})$, Aztreonam $(30 \mu \mathrm{g})$, Cefoxitin $(30 \mu \mathrm{g})$, Ceftriaxone $(30 \mu \mathrm{g})$, Ceftazidime $(30 \mu \mathrm{g})$, Cefuroxime $(30 \mu \mathrm{g})$, Imipenem $(10 \mu \mathrm{g})$, Tetracycline $(30 \mu \mathrm{g})$, Minocycline $(30 \mu \mathrm{g})$, Gentamicin $(15 \mu \mathrm{g})$, Tobramycin $(10 \mu \mathrm{g})$, Amikacin $30 \mu \mathrm{g}$, Nalidixic $\operatorname{acid}(30 \mu \mathrm{g})$, Norfloxacin $(5 \mu \mathrm{g})$, Ciprofloxacin $(5 \mu \mathrm{g})$, Chloramphenicol $(30 \mu \mathrm{g})$, Colistin $(50 \mu \mathrm{g})$ and Trimethoprim / Sulfamethoxazole (25 $\mu \mathrm{g})$. The antibiotics were produced by Bio$\mathrm{Rad}$.

\section{Results and Discussion}

\section{Prevalence of Salmonella}

A total of 84 strains of Salmonella were isolated from the 420 cow dung samples tested, a prevalence of $20 \%$. The municipality of Port-Bouët has the highest prevalence rate with $9.8 \%$, followed by Adjamé (7\%), Abobo (1.2\%). The lowest prevalences were observed in Yopougon and Bingerville (Table 2).

\section{Serotyping}

The serotyping was carried out entirely for 33 strains. Salmonella isolates was distributed in twenty-three (23) different serotypes (Table $3)$.

S. muguga (2), S. agbeni (4), S. II (6), S. virchow (1), S. IIIa (2), S. enteritidis (1), $S$. neumuenster (1), S. othmerschen (1), $S$. 
parkroyal (1), S. senftenberg (1), S. umbadah (1), S. Dessau (1), S. tudu (1), S. muenster (1), S. gustavia (1), S. canton, S. salford (1), $S$. africana (1), S. bradford (1), S. chicago (1), S. erfut (1), S. bron (1), S. typhi (1).

\section{Antimicrobial susceptibility testing}

\section{Resistance to an antibiotic}

A total of 54 strains of Salmonella was subjected to the antibiotic sensitivity test (antibiogram), 46.3\% (25/54) of the strains exhibited resistance to at least one antibiotic. These strains showed resistance to colistin $(24.1 \%)$, tetracycline $(22.2 \%)$, minocycline (20.4\%), trimethoprim / sulfamethoxazole $(9.3 \%)$, nalidixic acid $(7.4 \%)$, norfloxacin (5.6\%), ciprofloxacin $(5.6 \%)$, tobramycine $(5.6 \%)$, cefalotin $(3.7 \%)$, ceftazidime $(1.9 \%)$, cefoxitin (1.9\%), ceftriaxone $(1.9 \%)$, amoxicillin + clavulanic acid (1.9\%), aztreonam (1.9\%), cefepime, Cefuroxim (1.9\%) and Ampicillin (1.9\%)

\section{Phenotypes of resistant serovars}

Of the 54 strains tested $22.22 \%$ of the strains (12/54) showed resistance to at least one antibiotic and $24.07 \%$ of the strains (13/54) showed resistance to at least 2 antibiotics
(Tables 4 and 5). However, $53.7 \%$ of the strains (29/54) were sensitive to the antibiotics used (Table 3 ).

The prevalence of Salmonella in the cow dung samples tested in our study was $20 \%$. This could be explained due to the fact that Salmonellae are naturally present in the digestive tract of warm-blooded animals (Bourgeois and Leveau, 1991).

In this study the prevalence $(20 \%)$ is much higher than that reported by Fegan et al., (2004) in Australia, which was 6.88\%. In the United States, the prevalence of Salmonella in cattle faeces in farms was reported to be less than 7\% (Losinger et al., 1997; Fedorka-Cray et al., 1998; Dargatzet et al., 2003). The presence of Salmonella in cattle could be linked, on one hand, to the cattle rearing method and, on the other hand, to the contamination of the breeding sites which are located in township therefore subjected to the influence of the activities of the population. This situation will encourage the circulation and spreading of Salmonella. In Côte d'Ivoire, no studies on Salmonella prevalence in cattle breeding have been reported, but studies by Traoré (2003) and Ouattara (2005) in poultry farming has reported Salmonella prevalence rates of $56 \%$ and $52 \%$ respectively.

Table.1 Biochemical and morphological character of Salmonella

Biochemical and morphological character of Salmonella

\section{glc $^{+} \operatorname{lac}^{-} \mathbf{H}_{2} \mathrm{~S}^{+}$ur $^{-}$ind $^{-} \mathrm{LDC}^{+} \mathrm{bg}^{-} \mathrm{mob}^{+}$gas $^{+} \mathrm{cat}^{+}$ox $^{-}$}

$\mathrm{Glc}^{+}=$glucose fermentation; lac ${ }^{-}=$no oxidation of lactose; $\mathrm{H}_{2} \mathrm{~S}^{+}=$hydrogen sulfide production; ur $^{-}=$no production of urease; ind ${ }^{-}=$no production of indole; $\mathrm{LDC}^{+}=$production of lysine decarboxylase; $\mathrm{bg}^{-}=$gram-negative bacilli; $\mathrm{mob}^{+}=$presence of mobility; gas $^{+}=$gas production; cat $^{+}=$production of catalase; ox $=$no production of oxidase.

Table.2 Prevalence of Salmonellas isolated from the cow dung in the District of Abidjan

\begin{tabular}{lcccccc}
\hline & \multicolumn{6}{c}{ Distribution of Salmonellas in the different municipalities } \\
\cline { 2 - 6 } & Abobo & Adjamé & Yopougon & Bingerville & Port-Bouët & Total \\
\hline Number of sample & $\mathrm{n}=60$ & $\mathrm{n}=60$ & $\mathrm{n}=60$ & $\mathrm{n}=60$ & $\mathrm{n}=180$ & 420 \\
\hline Numberof Salmonelle $(\mathbf{n}(\boldsymbol{\%}))$ & $\mathbf{5 ( 1 , 2 \% )}$ & $\mathbf{3 0}(\mathbf{7 \%})$ & $\mathbf{4 ( 1 \% )}$ & $\mathbf{4 ( 1 \% )}$ & $\mathbf{4 1}(\mathbf{9 , 8 \%})$ & $\mathbf{8 4}(\mathbf{2 0 \%})$ \\
\hline
\end{tabular}


Table.3 serotypes of isolated Salmonella spp strains

\begin{tabular}{ll}
\hline Serotype & Number \\
\hline S. muguga & 2 \\
\hline S. agbeni & 4 \\
\hline S. II & 6 \\
\hline S. IIIa & 2 \\
\hline S. virchow & 1 \\
\hline S. enteritidis & 1 \\
\hline S. neumuenster & 1 \\
\hline S. canton & 1 \\
\hline S. othmerschen & 1 \\
\hline S. parkroyal & 1 \\
\hline S. senftenberg & 1 \\
\hline S. umbadah & 1 \\
\hline S. dessau & 1 \\
\hline S. tudu & 1 \\
\hline S. muenster & 1 \\
\hline S. gustavia & 1 \\
\hline S. salford & 1 \\
\hline S. africana & 1 \\
\hline S. bradfort & 1 \\
\hline S.chicago & 1 \\
\hline S. erfut & 1 \\
\hline S.bron & 1 \\
\hline S. typhi & 1 \\
\hline Salmonella. sp & 51 \\
\hline & \\
\hline
\end{tabular}

Table.4 Phenotypes of resistant strains to single antibiotic

\begin{tabular}{lll}
\hline Sample & Serotypes & Phenotypes \\
\hline E44S & S. enteritidis & Tmn \\
\hline E46S & S. neumenster & Cst \\
\hline E67S/B & S. senftenberg & Sxt \\
\hline E61S & S. agbeni & Cst \\
\hline E74S & S. dessau & Sxt \\
\hline E111S/B & S. $s p$ & Cst \\
\hline E45ADS/B & S. $s p$ & Cst \\
\hline E43ADS/C & S. $s p$ & Cst \\
\hline E43ADS/B & S. $s p$ & Cst \\
\hline E42ABS & S. $s p$ & Cst \\
\hline E73S & Umbadah & Tmn \\
\hline E92S & S. $s p$ & Cst \\
\hline
\end{tabular}


Table.5 Phenotypes of resistant strains to at least 2 antibiotics

\begin{tabular}{lll}
\hline Sample & Serotypes & Phenotypes \\
\hline E64S & S. II & CefCstMnoTet \\
\hline E32S & S. virchow & SxtMnoTetNalNorCip \\
\hline E38S & S. IIIa & MnoTet \\
\hline E60S & S. $s p$ & CstTmn \\
\hline E68S & S. $s p$ & SxtMnoTet \\
\hline E88S & S. II & NalNorCip \\
\hline E89S & S. $g$ ustavia & TetMnoNalNorCip \\
\hline E108S & S. $s p$ & CstMnoTet \\
\hline E28ADS & S. $s p$ & CstMnoTet \\
\hline E29PBS/B & S. $s p$ & MnoNalTet \\
\hline E66S & S. $s p$ & MnoTet \\
\hline E90S & S. $s p$ & MnoTet \\
\hline E28ABS/C & S. $s p$ & CazFoxCroAmcAtmFepCepS \\
& & xtCxmCstAmpMnoTet \\
\hline
\end{tabular}

Fig.1 Profile of resistance to antibiotics of Salmonella strains

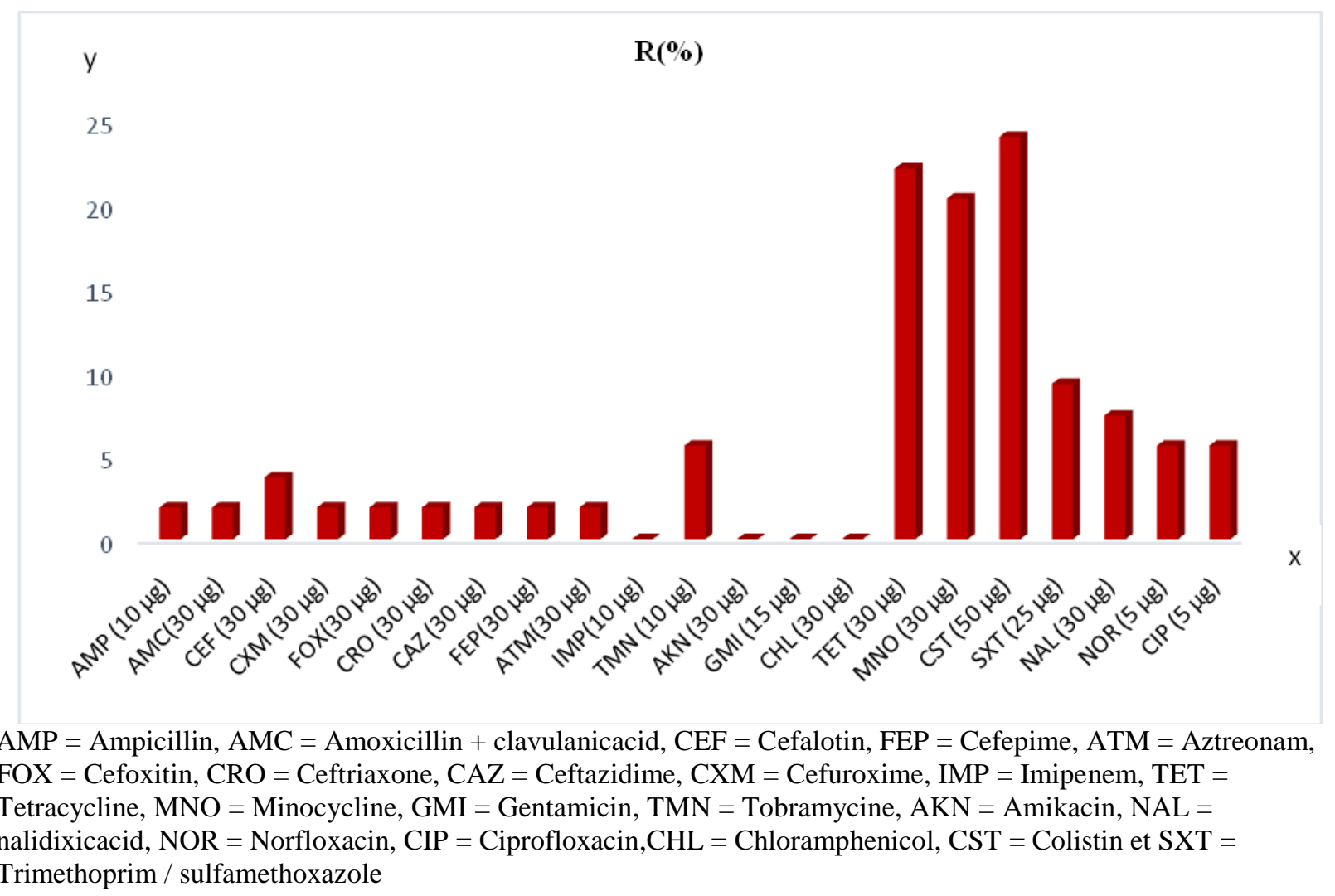

Salmonella strains subjected to serotyping gave 23 different serotypes and also showed a predominance of Salmonella II (6/33). The frequency of isolation of serovars varies according to region and even country Khar (2006). Resistance profiles obtained in this 
study showed a resistance rate of $22.2 \%$ for colistin, $16.7 \%$ for tetracycline, $16.7 \%$ for minocycline, $7.4 \%$ for trimethoprim / sulfamethoxazole, $7.4 \%$ for nalidixic acid, $5.6 \%$ for norfloxacin, $5.6 \%$ for ciprofloxacin, $3.7 \%$ for tobramycin and $1.9 \%$ for cefalotine (Fig. 1). Study results do not corroborate to that of Ahi et al., (1990), who, according to him between 1980 and 1988, all Salmonellae isolated in Côte d'Ivoire were sensitive to fluoroquinolones, on the other hand, these results are in agreement with the works of Coulibaly et al., (2009). Salmonellae are enterobacteriaceae (Yan et al., 2003), naturally sensitive to betalactamins, aminoglycosides, quinolones, fluoroquinolones and nitrofurantoin. Therefore, strains sensitive to all families of antibiotics could be purely wild strains. This would explain why the acquisition of a multiresistance character would be caused by the misuse of antibiotics in the prophylactic and metaphylactic treatments of animals. Resistance to colistin was rarely observed despite selection pressure (Jensen et al., 1987, Pit et al., 2003), it remains the last choice antibiotic when the use of an antibiotic of the betalactamin family Aminoglycosides, or quinolones seems to be inefficient (Livermore, 2002). The resistance to colistin would come from the contamination of the herds of their immediate environment.

In conclusion, this study showed a high prevalence of Salmonella in cattle rearing. Contamination of the environment by these germs can cause the occurrence of infectious diseases in humans and in cattle. For this purpose, further study on Salmonella in cattle should be taken in order to determine their pathogenic factors. To check the transmission and spreading of Salmonella in cattle breeding biosecurity measures must be taken. Finally, the use of antibiotics in cattle breeding should only be done if necessary to avoid resistant strains of Salmonella to antibiotics.

\section{References}

Ahi, K. 1990. Contribution à l'étude de 1'espèce Salmonella en Côte d'Ivoire. ThèseMéd. Abidjan. Côte d'Ivoire. 133 p.

Assoumy, A.M. 2009. Contribution à la codification, à l'analyse des statistiques d'importation et à l'étude de qualité des médicaments vétérinaires en Côte d'Ivoire: cas d'Abidjan, d'Anyama et de Bingerville, Thèse de medicine Vétérinaire, Ecole inter-états des Sciences et Médecine Vétérinaires de Dakar, Sénégal, 232p.

Bauer, A.W., W.M. Kirby, J.C. Sherris and Turck, M. 1966. Antibiotic susceptibility testing by a standardized single disk method. American J. Clin. Pathol., 45: 493-496.

Bean, N. H., J. S. Goulding, M.T. Daniels and Angulo, F.J. 1997. Surveillance for foodborne disease outbreaks - United States, 1988-1992. J. Food Protection. 60: 1265-1286.

Bourgeois C.M et Leveau J.Y., 1991. Le contrôle microbiologique: Techniques d'analyse et de contrôle dans les industries Agroalimentaires, collection Sciences et techniques agroalimentaire, 3(2): 260-266.

Brooks, J.T., Matyas, B.T., Fontana, J., DeGroot, M.A., Beuchat, L.R., Hoekstra, M. and Friedman, C.R. 2012. An outbreak of Salmonella serotype Typhimurium infections with an unusually long incubation period. Foodborne Pathog. Dis., 9: 245-248

Coulibaly, E.K., Bakayoko, S., Karou, T.G., Coulibaly, K.J., Goualie, G.B., Dosso, M., and Diopoh, K.J. 2009. Serotyping and antimicrobial resistance of Salmonella strains isolated from the livers of chickens sold in the markets of Yopougon (Abidjan Côte d'Ivoire) in 2005. RASPA 8: 1-6. 
Coulibaly, K.J., Bakayoko, S., Coulibaly, E.K., Karou, G.T., Goualie, G.B., Akesse, L., Gbonon, C., Boni-Cisse, C., Koffi, K.S., Ekaza, E., N'Douba, A. and Dosso, M. 2010. Biodiversité des Salmonella à Abidjan: Etude des isolats de 2003 à 2009 par le centre de référence de 1'Institut Pasteur, RASPA, $8: 25-30$

Dargatz, D.A., Fedorka-Cray, P.J., Ladely, S.R., Kopral, C.A., Ferris, K.E. and Headrick, M.L. 2003. Prevalence and antimicrobial susceptibility of Salmonella spp. isolates from US cattle in feedlots in 1999 and 2000. J. Appl. Microbiol., 95: 753-761.

Dubroca S., Correge I., Goueset M., Guyomard F., Loiseau m., Salaum Y., Minvielle B., et Le Roux A. 2005. Caractérisation du statut «salmonelles » d'un élevage de porcs: Analyse comparée de la sérologie et de la bactériologie. Epidémiol etSanté Anim. 48: 41-49.

Fedorka-Cray., Dargatz P.J, D.A., Thomas, L.A. and Gray, J.T. 1998. Survey of Salmonella serotypes in feedlot cattle. $J$. Food Protection, 61: 525-530.

Fegan, N., Vanderlinde, P., Higgs, G. and Desmarchelier, P. 2004. Quantification and prevalence of Salmonella in beef cattle presenting at slaughter, J. Appl. Microbiol., 97: 892-898.

Flint, J.A., Van Duynhoven, Y.T., Angulo, F.J., DeLong, S. M., Braun, P., Kirk, M., Scallan, E., Fitzgerald, M., Adak, G. K., Sockett, P., Ellis, A., Hall, G., Gargouri, N., Walke, H., and Braam, P. 2005. Estimating the burden of acute gastroenteritis, foodborne disease, and pathogens commonly transmitted by food: an international review. Clin. Infect. Dis., 41(5): 698-704. Epub 2005 Jul 22. 41, 698-704.

ISO 6579. 2002(E). Microbiology - General guidance on methods for the detection of Salmonella, International Organization for Standardization, Geneve, Switzerland,4rd ed.

Janmohamed, K., Zenner, D., Little, C., Lane, C., Wain, J., Charlett, A., Adak, B. and Morgan, D. 2011. National outbreak of Salmonella Enteritidis phage type 14b in England, September to December 2009: case-control study. Euro Surveill. 16. Pii: 19840.

Jensen, T, Pedersen, S.S, and Garne, S.1987. Colistin inhalation therapy in cystic fibrosis patients with chronic Pseudomonas aeruginosa lung infection. J. Antimicrobial Chemother., 19: 831-8.

Jung, S.C., Song, S.W., Kim, S.I., Jung, M.E., Kim, K.H., Lee, J.Y. and Lim, S.K. 2007. Surveillance of antimicrobial susceptibility of bacteria isolated from slaughterhouse in Korea. 2. Antimicrobial susceptibility of Salmonella spp. isolated from carcasses in slaughterhouse. Kor. J. Vet. Public Health, 31: 51-56.

Kane, M. 2008. Enregistrement, contrôle et harmonisation des législations sur les médicaments à usage vétérinaire en Afrique de l'Ouest. Conférence de l'OIE sur les médicaments vétérinaires en Afrique, 25-27 mars 2008, Dakar, Sénégal, pp 1-11

Karou, G.T, Ouattara, H, Bakayoko, S. 2013. Prevalence of Salmonella and distribution of Serovars Isolated from Retail Raw Chicken Gizzards in Abidjan, Côte D'ivoire. Octa. J. Biosci., Vol. 1(2): 115-121.

Lailler, R., Moury, F., Leclerc, V., Bohnert, M., Cadel-Six, S., and Brisabois, A. 2015. Surveillance de Salmonella dans la chaîne alimentaire pour la détection d'émergences en France. Bulletin épidémiologique, santé animale et ali mentation 68: 11-16.

Livermore, D.M. 2002. Multiple mechanisms of antimicrobial resistance in 
Pseudomonas aeruginosa: our worst nightmare? Clin. Infect. Dis., 34: 40634.

Losinger, W.C., Garber, L.P., Smith, M.A., Hurd, S.H., Biehl, L.G., Fedorka-Cray, P.J., Thomas, L., and Ferris, K., 1997. Management and nutritional factors associated with the detection of Salmonella sp from cattle fecal specimens from feedlot operations in the United States. Preventative Vet. Med., 31: 231-244.

Mc Donough, P.L., Fogelman D, Shin S.I., Brunner M.A and Lein D.H. 1999. Salmonella enteric serotype Dublin infection: an emerging infectious disease for the northeastern United States, I. Clin. Microbiol., pp: 2418-
2427.

Mohammad Hosein Movassagh, Mohammad Shakoori and Jalii Zolfaghari. 2010. The Prevalence of Salmonella spp. In Bovine Carcass at Tabriz Slaughterhouse, Iran, Global Veterinaria, 5(2): 146-149.

Pitt, T.L., Sparrow, M., Warner, M. 2003. Survey of resistance of Pseudomonas aeruginosa from UK patients with cystic fibrosis to six commonly prescribed antimicrobial agents. Thorax, 58: 6-79

Yan, S.S., ML. Pendrak, B. Abela-Ridder, I.W. Punderson, D.P. Pedorko and S.L. Foley, 2003. An overview of Salmonella typing public health perspectives, Clin. Appl. Immunol. Rev., 4(3): 189-204.

\section{How to cite this article:}

Yao Kouamé René, Coulibaly Kalpy Julien, Cissé Souleymane, Tiécoura Kouakou Bertin, Goualié Glossi Bernadette, Gueu Kpon Roméo, Yapi Houphouët Felix et Djaman Alico Joseph. 2017. Prevalence of Salmonella Strains in Cattle Breeding in the District of Abidjan (Côte d'Ivoire). Int.J.Curr.Microbiol.App.Sci. 6(3): 1154-1162. doi: https://doi.org/10.20546/ijcmas.2017.603.134 